\title{
AOR
}

Selected Papers of \#AoIR2020:

The $21^{\text {st }}$ Annual Conference of the

Association of Internet Researchers

Virtual Event / 27-31 October 2020

\section{VIRAL MUSICKING: AESTHETICS AND ITERATION IN ONLINE CONTAGION}

Paula Clare Harper

Washington University in St. Louis

Cats at keyboards. Dancing hamsters. A photo of a dress, and videos set to "Harlem Shake."

The above are recognizable as "viral" phenomena-artifacts of the early twenty-first century whose production and dissemination were facilitated by the internet, proliferating social media platforms, and ubiquitous digital devices. In this paper, I argue that participation in such phenomena (producing, consuming, circulating, or "sharing" them) constitutes a significant site of twenty-first-century musical practice: viral musicking, to adopt and adapt Christopher Small's foundational 1998 coinage. ${ }^{1}$

I use this term broadly- "viral musicking" comprises the viral circulation of clearlymusical objects (like music videos), as well as the musicalizing of viral material, but I also want to open up space for considering viral circulation itself as "musical" in nature. Some recent media scholarship has enthusiastically adopted sonic metaphors to describe digital culture and behavior-from the imagined democratization of digital "voice" to Kate Crawford's 2009 theorization of social media "listening."2 This paper pivots to investigate how such metaphors interface with sounds themselves, and how online virality might be productively understood within a framework of musical practice. Closely cribbing Christopher Small's formative 1998 theorization, in which he verb-ed the noun "music" to expand its purview and to more fully account for its ability to enact relationships, I define "to viral-music," as:

to take part in a performance of viral music in any capacity, whether by performing and/or providing material, by viewing/listening, by remixing or

\footnotetext{
${ }^{1}$ Christopher Small, Musicking: The Meanings of Performing and Listening (Middletown: Wesleyan University Press, 1998).

2 Kate Crawford, "Following You: Disciplines of Listening in Social Media," Continuum 23/4 (2009): 525535.

Suggested Citation (APA): Harper, P. (2020, October). Viral Musicking: Aesthetics and Iteration in Online Contagion. Paper presented at AolR 2020: The 21 $1^{\text {th }}$ Annual Conference of the Association of Internet Researchers. Virtual Event: AolR. Retrieved from http://spir.aoir.org.
} 
remediating, or by sharing that material-giving it the potential to pass on and "infect" new "hosts."

I value the productive friction embedded within the term "viral musicking," which forces proximity between the human-forward sociality of Small's "musicking" concept, and "viral"-a term somewhat famously rejected by media scholar Henry Jenkins, for its tendency to construe users as passive zombie hosts. ${ }^{4}$ In my conception of "viral musicking," I seek to highlight this tension. For me, the term foregrounds ambivalences bound up in digital viral circulation: of bodily threat and aesthetic pleasure, of constant negotiation between everyday users, powerful platforms, and black-boxed nonhuman algorithms.

The notion of virus as a metaphor for cultural spread is often traced to computer science and science fiction, with subsequent co-option into marketing and media; such formulations run adjacent to the popularization of "virus" in philosophical models for globalization and pervasive capitalism across the late twentieth century, from Derrida to Baudrillard and Deleuze. I seek to braid these lineages with the work of scholars reading cultural contagion through lenses of alterity and difference, in particular those who situate music as a particularly felicitous vector for viral contagion, exceeding and preceding Internet circulation. ${ }^{5}$

In this paper, I analyze instances of viral musicking from the 2000s through the present day, from GeoCities to TikTok, tracking viral circulation as heterogeneous, capacious, and contradictory-a dynamic, relational assemblage of both "new" and "old" media and practices. My methodology for analyzing viral musicking bricolages musicological toolkits (like those for the analyses of voice, genre, form, and repetition) with media archeology, digital autoethnography, and - crucially—a hybrid (even "analog") method of twenty-first-century reception history and discourse analysis. This latter approach holds more similarities to traditional archival methods than the material under analysis might seem to suggest-clicking, paging, and reading through masses of recorded documents to find consensus, contradiction, and latent coherences-but the archives I'm studying are digital media platforms, and the documents are YouTube comments and tweets, blogposts and technology news columns. Reading across these archives, I collate and analyze reactions - both vernacular and institutional, creative and critical-to viral phenomena.

This paper theorizes some of the characteristic structures of viral musicking in a twentyfirst-century context—structures that are looping and cyclical, irritating and iterative.

${ }^{3}$ See Small, Musicking, 9.

${ }^{4}$ Henry Jenkins, Xiaochang Li, Ana Domb Krauskopf, and Joshua Green, "If It Doesn't Spread, It's Dead (Part One): Media Viruses and Memes," henryjenkins.org, 2 February 2009.

http://henryjenkins.org/blog/2009/02/if it doesnt spread its dead p.html.

${ }^{5}$ See Barbara Browning, Infectious Rhythm: Metaphors of Contagion and the Spread of African Culture (New York: Routledge, 1998); Ronak K. Kapadia, "Sonic Contagions: Bird Flu, Bandung, and the Queer Cartographies of MIA," Journal of Popular Music Studies, 26/2-3 (2014): 226-250; James Gordon Kennaway, Bad Vibrations: The History of the Idea of Music as a Cause of Disease (Farnham: Ashgate, 2012). 
Some come at the level of form: loops in content, small units of image and sound compelled to repeat indefinitely. Often, digital architectures mirror or reinforce these loops; from the WebRings of the 1990s, to the modules of a contemporary social media feed, viral content circulates on structures that iterate or that loop back on themselvesstructures that afford repetition and repeated encounter. More social operations of virality, like remix or alteration, are achieved by the making and sharing of new versions that simultaneously clearly reference the original, and provide an aspect of novelty or surprise. Additionally, most instances of digital virality feature the mediation of the original content into new platforms - in particular, coverage of digital virality by "old" or "legacy" media like print journalism or television. These engagements with virality might be envisioned as coils or helixes, expanding outwards concentrically from the original object, but also orbiting back in, redirecting attention back to the original viral objectand, with attention, potential new "hosts."

But despite the resemblance of cyclical patterns across different instances of internet virality, I will also endeavor to show that these loops change and shift diachronically: "viral musicking" has evolved and adapted alongside the proliferation and growing ubiquity of digital devices, platforms, and software over the course of the twenty-first century. Consequently, "going viral" in 1999 was different than "going viral" in 2006, or 2011, or 2020 - in part because viral musicking, and the participatory practices associated with online virality, were distinct as well.

Ultimately, I argue that viral musicking activates utopian promises of digital advocates, through the cooperative social operation of "sharing," even as it resonates through histories and presents of racialization, miscegenation, appropriation, and the realities of porous, breachable borders, cultures, and bodies. Further, this paper demonstrates how participation in the genres and performances of viral musicking has served to normalize and neutralize early twenty-first $t^{t}$-century conditions of pervasive advertising, data collection, and surveillance. 